\title{
Effect of Self-Organized Learning Environment on the Comprehension of ESL Learners at Primary Level in Pakistan
}

\author{
Muhammad Akram ${ }^{1} \&$ Mamuna Ghani ${ }^{1}$ \\ ${ }^{1}$ Department of English, The Islamia University of Bahawalpur, Pakistan \\ Correspondence: Muhammad Akram, Department of English, The Islamia University of Bahawalpur, Pakistan. \\ E-mail: muhammadakramw@gmail.com
}

Received: October 6, 2018 Accepted: November 3, 2018 Online Published: December 29, 2018

doi:10.5539/ijel.v9n1p135 URL: https://doi.org/10.5539/ijel.v9n1p135

\begin{abstract}
The research is designed to study the effect of self-organized learning environment (SOLE) on the comprehension of the learners of English as Second Language at primary level in Pakistan. This study is conducted under the influence of Mitra (1999) experiments in child driven education. By using convenient sampling, two groups of thirty two ESL learners of grade 5th from one government school are selected randomly for the research. To find out whether SOLE is effective for learning comprehension, the researchers have used quasi experiment. The tools used for this experiment are pretest and posttest. One group of thirty two students is taken as controlled group and is taught how to have ESL comprehension by traditional method. The other group is experimental group and the researchers leave the learners in IT lab to learn ESL comprehension independently. The researchers assign some tasks to the learners and they complete these tasks by using computer on their own. After the experiment of 20 days it has been found from the comparison of the results gained through posttest from both the groups that the effect of self-organized learning environment on the comprehension of ESL learners is more than the traditional learning environment. The aim of this study is to enable the learners to learn English comprehension by the use of computer under self-organized learning environment.
\end{abstract}

Keywords: SOLE, ESL, self-child driven school

\section{Introduction}

Humans are born with innate capabilities. The first thing they learn in womb of their mother is swimming. Then after their birth they learn sucking, cooing, crying, smiling, crawling, walking, drinking, eating and speaking. Sharma and Cockerill (2014) are of the view that almost all the humans go through these above mentioned stages. Learning is a social phenomenon along with biological capacity to learn. So, in social environment of learning, all these stages of learning are experienced by all humans in a usual order in a natural way (Medina, 2014). It is not only natural but also self-organized. Language learning is very much like that of other biological processes of human beings (Jenkins, 1990). As human beings are social animals, they are always in a state of flux of learning. Sometimes people learn from their environment, sometimes they learn from other people, sometimes, they learn from their experiences and sometimes they learn silently from nature. It means learners learn from the environment automatically. Human beings use all their skills to interact with environmental factors to learn about. In ancient times, people of rocks used to live in caves, hunt with stones and cook food with the help of fire which was also lit up with the help of stones. With the passage of time learning styles and ways changed. Now it is 21 st century, the Century of information technology (IT). The invention of computer and internet has revolutionized the learning process. SOLE actually stands for self-organized learning environment. It is a learning process which is used to having ESL comprehension in the current studies. The process involves computer, internet and ESL learners.

\subsection{Objective of the Study}

The objective of the present study is to enable the ESL learners to comprehend the statements and find the possible answers. For this purpose, the researchers have used SOLE to enhance the comprehension skill of ESL learners. 


\subsection{Theoretical Background}

The self -organized learning environment (SOLE) is a term used by Mitra (1999) after an experiment which is known as "The Hole in the Wall". The experiment was that Mitra (1999) embedded computer with internet in the wall of slum area of Delhi. He did this experiment due to the shortage of teachers. India is a populous country and ESL learners are more in numbers than the teachers needed. Students are deprived of skillful teachers. It is a bitter fact that in backward area the teachers, especially good and competent ones, hesitate to go. Mitra (1999) observed that without teachers, students learnt to operate computer and use Google. They started to take help from Google for their homework. The school teachers observed a great change among students' learning behavior. The learners became more creative and their English skills were also improved. On the basis of this experiment, Mitra (1999) proposed the SOLE. Now he has started several related projects all over the world. The aims of the SOLE are: 1) to enable learners to use computer and internet; 2) to learn English by the use of email, browser and chat; 3 ) to enhance curiosity to know answer of questions; 4) to improve learner listening, speaking, reading and writing (LSRW) skills by the use of computer in few months; 5) to enhance their communication skill or spoken skill; and 6) to make them independent learner. These are the major aims of the SOLE. The most interesting thing is how to use the SOLE. There are some rules to deal with the SOLE. These are following: 1) students are divided into groups, four students in each group; 2) students are free to choose their group; 3) they can change the group at any time; 4) they interact with other groups and bring back some information to their group. A task is given to students and a computer with internet is provided to them to solve the task-related issue independently. But they can also take views of their fellows in order to solve the problem. The role of teacher is passive in this learning. Many schools and organizations are working on the concept of the SOLE in Pakistan. In Pakistan, Salahuddin Khawaja (2015) (Note 1) has built a school in Lahore and an organization Khud (2016) (Note 2) is also working in Lahore on the pattern of SOLE. Numerous SOLE based projects are being run in various parts of the world and they are getting fruitful results.

\section{Literature Review}

Humans have curiosity in their nature and they want to explore every corner of the world with the capacity bestowed upon them. Gottlieb, Lopes, and Oudeyer (2016) have observed that humans have curiosity about things around them and this curiosity is satiated only when appeased. It is evident from the history of mankind that human beings have been successful to deal with the world and have found the ways of survival by using their skills and environment. Spradley (2016) talks about the human behavior by saying that prior to make comments and "impose your theories on the people you study, find out how those people define the world."

For Kolb (2014), the known human history starts with the Stone Age. In the Stone Age humans used stones to make shelter, to prepare food and to protect themselves. They lived in caves of stones, used stones for fire and also for hunting. The next ages were Bronze and Iron Ages. Kolb (2014) states that, with passing of all these developing stages, human beings learnt new skills to coup up with the emerging problems. They have inborn ability to struggle against the negative forces (Sigelman \& Rider, 2014). So, they continued struggle and the reward of the struggle was development and learning in the physical as well conceptual world.

Along with the material growth, human beings also developed the sense of dealing with that material. Descartes (1978) states that the world consists of two things: "perceiving mind" and "matter". He further explains that "perceiving mind" represents the psychological part, and "matter" shows the physical part of the world (1978). For him, it is perceiving mind which interacts with dead physical part to give meaning to it. Descartes (1978) and Kim (2018) further explain that the perceiving mind deals with the physical world and gives meaning to that physical part. It means that perceiving mind is actually a psychological world that everyone has. Shaw and Bransford (2017) have also given the same idea about human psychology that even animals and humans observe and perceive events accordingly. They are of the view that "It is the perceiver who knows and the knower who perceives" (Shaw \& Bransford, 2017).That's why each person has his/her own perspective to see this physical world. So, all humans differ from each other due to this perceiving mind. Descartes (1978) is of the view that perceiving mind also refers to cognition, and objects in the world refer to matter or physical world. Humans have ability to deal with the physical world by using cognition or perceiving mind in a better way. It means that humans are self-organized. Learning processes and manners have been discussed by many theorists and educationists. Gass (2017) states that "learning can be linked, using cognitive concepts derived". According to Chomsky $(1975,2000)$ in child's mind there is a framework of instruction and the mind can create different structures by using these instructions. He further illustrates that this framework helps to give names to the objects and feelings; thus, it gives birth to a language. He further elaborates that like other biological aspects, acquisition of language is also a biological process. Weisberg and Reeves (2013) also emphasize about the creative ability of cognition. 
Crain and Nakayama (1987) elaborate that "Elicitation tasks are used to gain the background or early knowledge of learners". Elicitation process or any such task stimulates the cognition of the learner to think over the given topic by using early or basic knowledge. It is helpful to enhance or sharpen the cognition process of the learner. Lave, Wenger, and Wenger (1991) explain how to check learning of learners as they think that test is a good source to establish the value of knowledge, and with the help of learning style, knowledge can be enhanced. It means by using the tests system, the knowledge of learners can be checked and evaluated. This evaluation of knowledge helps further in improvement of learning process or styles.

The development of technology has also influenced the learning process. In the modern world, technology and Education development seem inseparable parts (Barrett \& Liu, 2016). During the last three decades, various gadgets have been used for teaching and learning purposes. These devices have become inevitable part of our life as their use is common to all. Now cell phones, computer devices and internet have become part and parcel of our life. Digital technology has become a powerful tool in the development of education (Mukti \& Hwa, 2004; Peeraer \& Van Petegem, 2011). The growing use of technology in every field of life, especially education, has given boom to it, and it has also enhanced its innovative quality (Fong, 2009; Poorfaraj, Samimi, \& Keshavarz, 2011). The new generation is not unfamiliar with this digital technology as they seem to know the modern trends (Robertson, Fluck, \& Webb, 2007). Thus, teachers have to be well-prepared for the digitalized world (Robertson et al., 2007; Smolin \& Lawless, 2007). ELT teachers are also using Web-based programs to cope up with the modern needs of teaching and learning. Though adoption of technology has given a lot of challenges to the teachers, yet their adoption is also an essential part to counter the day to day challenges (Barrett \& Liu, 2016). It is also used to lower the anxiety of the ESL learners (Rahimi \& Yadollahi, 2011).

Gardner (1987) is of the view that "Human brain is like computer machine and arrange cognitive symbols in framework of brain". It means that in a computer the information or data is saved already. When something is asked, computer uses its artificial cognition or memory to use that information present there and solve the problem (Kondo \& Fukumura, 2016). In human beings, the function of brain is just like that of a computer and it works in the same pattern as it uses original or natural cognition to sort out the problem (Card, 2017; Graves et al., 2016).

Swenson (1997a, 1997b) states that an experience can be decomposed and then become the part of self-organized model of human development. It tells that when human passes through an experience, it absorbs in humans' practical approach. Giving almost the similar view, Oudeyer and Smith (2016) say that humans develop self-organized learning through the dynamic interaction.

Mitra (1999) proposed a new learning style of SOLE. According to him, humans have capability to learn self-learning from environment. To prove this, he (1999) did an experiment named "The Hole in the Wall". He embedded computer in the wall with internet in slum area of Delhi. After two months the learners who used to move in the street during the experiment time, learnt to operate computer and google it. He concluded that learners could learn effectively by SOLE without teachers. O'Leonard (2013) explains the importance of online self-study or virtual classes by survey in U.S. The survey throws light on the droppage of learning through classroom-based process while it rose in online self-study and virtual class-rooms.

Change seems the only permanent quality of life. With the passage of time, learning styles and strategies are developed. New styles and techniques are being introduced as learning strategies in the fields of learning, especially second language learning. Reid (1995) define Style as an indication of preferred or habitual pattern of dealing with the things. Wong and Nunan (2011) illustrate the style in terms of a way of approaching something.

\section{Method}

\subsection{Design of the Study}

The design of this study is quasi experiment. Pretest and posttest are part of this study. The aim of this study is to explore the learners' capabilities of handling the computer and internet to increase their comprehension. This study used the SOLE to enhance the comprehension skill of ESL learners.

\subsection{Participants}

The study took place in a Government primary school of Rahim Yar Khan. 64 students were taken from two sections of grade 5th. The test was taken to check English proficiency among 66 students. This test consisted of comprehension passage and its exercise. This test was designed to check students' basic understanding (attachment a).Students were selected after that test for this study. Two participants were not interested. Finally, 64 learners had participated in this study. 
Table 1. Demographic information

\begin{tabular}{lll}
\hline Groups & Number of students & Grade \\
\hline Controlled & 32 & $5^{\text {th }}$ \\
Experimental & 32 & $5^{\text {th }}$ \\
\hline
\end{tabular}

\subsection{Instruments}

The tools used in this experiment were pretest and posttest. The pretest consisted of comprehension passage (attachment a). The posttest also consisted of a comprehension passage (attachment b).

\subsection{Procedure}

In the start of experiment all learners were provided with pretest to check their present level before treatment. The period of treatment was 20 days. One group of twenty students was taken as controlled group and was taught how to do comprehension by traditional method. The other group was experimental group and the researchers left the learners in IT lab to let them learn ESL comprehension on their own. The researchers assigned some tasks to the learners and they completed these tasks by using computer by themselves. After 20 days the posttest was taken from both groups.

\section{Data Analysis}

The data of result of pretest and posttest of control and experimental groups were collected. Then t-test was applied on scores of pretest and posttest of both group. The quantitative analysis was obtained by putting scores from score sheet into Statistic Package for the Social Science (SPSS 21).

\section{Control Group}

Table 2. Descriptive statistics for pretest and posttest of control group

\begin{tabular}{llll}
\hline & Sample & Mean & Standard Deviation \\
\hline Pre-Test Control Group & 32 & 3.8906 & 1.25553 \\
Post Test Control Group & 32 & 4.9375 & 0.78030 \\
\hline
\end{tabular}

From Table 2 we conclude that average value of pretest is relatively lower than the post test of control group. This shows that posttest of control group is better than pretest of control group.

Table 3. Paired samples t-test for dependent sample of pretest and posttest of control group

\begin{tabular}{|c|c|c|c|c|c|c|}
\hline Pair & Mean & Standard deviation & S. E & $\mathrm{t}$ & df & p-value \\
\hline Pre-Test Control Group & & & & & & \\
\hline $\begin{array}{l}\text { Pair } \\
\text { Post-Test Control Group }\end{array}$ & 1.04688 & 1.32202 & .23370 & 4.480 & 1 & 0.000 \\
\hline
\end{tabular}

From Table 3 based on the pair t-test for dependent sample, we have to find that the result of $\mathrm{P}$ value $<\alpha=5 \%$. It clearly indicates the rejection of null hypothesis and shows that it is significant at $5 \%$ level of significance.

$\mathrm{H}_{0}=$ There is no effect of traditional teaching approach on the enhancement of comprehension of ESL learners at primary level.

$\mathrm{H}_{1}=$ There is an effect of traditional teaching approach on the enhancement of comprehension of ESL learners at primary level.

Experimental Group

Table 4. Descriptive statistics for pretest and posttest of experimental group

\begin{tabular}{llll}
\hline & Sample & Mean & Standard Deviation \\
\hline Pre-Test & 32 & 4.4844 & 0.84705 \\
Post Test & 32 & 5.3125 & 0.57851 \\
\hline
\end{tabular}


From Table 4 we conclude that average value of pretest is relatively lower than the post test of experimental group. This shows that there is difference between result of pretest and posttest of experimental group and it proves that the result of posttest is better than the result of pretest.

Table 5. Paired samples t-test for dependent sample of pretest and posttest of experimental group

\begin{tabular}{|c|c|c|c|c|c|c|}
\hline Experimental Group & Mean & Standard deviation & S. E & $\mathrm{t}$-Statistic & Df & p-value \\
\hline Pre-Test & & & & & & \\
\hline $\begin{array}{l}\text { Pair } \\
\text { Post Test }\end{array}$ & 0.82812 & 0.87630 & 0.15491 & 5.346 & 31 & 0.000 \\
\hline
\end{tabular}

From Table 5 based on the pair t-test for dependent sample, we have found that the result of, $\mathrm{P}$ value $<\alpha=5 \%$. It clearly indicates the rejection of null hypothesis and shows that it is highly significant at $5 \%$ level of significance.

$\mathrm{H}_{0}=$ There is no effect of multiple intelligence teaching approach on the enhancement of comprehension of ESL learners at primary level.

$\mathrm{H}_{1}=$ There is an effect of multiple intelligence teaching approach on the enhancement of comprehension of ESL learners at primary level.

For Independent Sample

Pre-test

Table 6. Descriptive statistics for pretest of experimental group and control group

\begin{tabular}{llll}
\hline & Sample & Mean & Standard Deviation \\
\hline Control Group & 32 & 3.8906 & 1.26831 \\
Experimental Group & 32 & 4.4844 & 0.84705 \\
\hline
\end{tabular}

From Table 6 we conclude that average value of pretest of control group is relatively lower than the pretest of experimental group. This shows that control group is better than experimental group in pretest result.

Table 7. Independent samples t-test of pretest for experimental and control group

\begin{tabular}{llllll}
\hline Pre-Test & Mean differences & Standard Error & $\mathrm{t}$ & $\mathrm{df}$ & $\mathrm{p}$-value \\
\hline t-test for equality of means & 0.59375 & 0.26961 & 2.202 & 62 & 0.031 \\
\hline
\end{tabular}

From Table 7 based on t-test for independent sample, we have to find that the result of $\mathrm{P}$ value $<\alpha=5 \%$. It clearly indicates the rejection of null hypothesis and shows that it is significant at $5 \%$ level of significance.

$\mathrm{H}_{0}=$ There will be no effect of teaching approach on the enhancement of comprehension of ESL learners at primary level.

$\mathrm{H}_{1}=$ There will be an effect of teaching approach on the enhancement of comprehension of ESL learners at primary level.

Post test

Table 8. Descriptive statistics for posttest of experimental group and control group

\begin{tabular}{llll}
\hline & Sample & Mean & Standard Deviation \\
\hline Control Group & 32 & 4.9375 & 0.78030 \\
Experimental Group & 32 & 5.3125 & 0.57851 \\
\hline
\end{tabular}

From Table 8 we conclude that average value of posttest of control group is relatively lower than the post test of experimental group. This shows that multiple intelligence approach of teaching has worked. 
Table 9. Independent samples t-test of posttest for experimental and control group

\begin{tabular}{llllll}
\hline Post Test & Mean differences & Standard Error & $\mathrm{T}$ & $\mathrm{df}$ & $\mathrm{p}$-value \\
\hline $\mathrm{t}$-test for equality of means & 0.37500 & 0.17171 & 2.184 & 62 & 0.033 \\
\hline
\end{tabular}

From Table 9 based on t-test for independent sample, we have to find that the result of, $\mathrm{P}$ value $<\alpha=5 \%$. It clearly indicates the rejection of null hypothesis and shows that it is significant at $5 \%$ level of significance.

$\mathrm{H}_{0}=$ There is no effect of multiple intelligence teaching approach on the enhancement of comprehension of ESL learners at primary level.

$\mathrm{H}^{1}=$ There is an effect of multiple intelligence teaching approach on the enhancement of comprehension of ESL learners at primary level.

\section{Conclusion}

The findings of the present study show that ESL learners learn English more effectively and proficiently with cooperation and collaboration with each other. The aim of this study was to inquire whether the SOLE would affect positively on enhancing the ratio of learning comprehension skill or not. The researchers took the two groups of ESL learners for the research purpose: one controlled and one experimental group. The students were given the opportunity to work on their own. The researchers did the experiment and made a hole in the wall. After 20 days, results taken through posttest showed a marked difference from the pretest data results. The students who were taught by traditional method showed the results which were not very much different from the pretest results. On the other hand, the experimental group showed the results which authenticated the methodology of Mitra (1999). The researchers have found that the SOLE is a teaching strategy which has very positive effect on the learning comprehension of ESL learners. It is not only helpful in enhancing the comprehension skill of ESL learners but also supportive in enhancing LSRW skills of ESL learners. It is the strategy that makes the learners more creative and independent as well. The researchers have also discovered the marvelous change in their confidence level.

\subsection{Limitations}

The data was collected from one school. The time for the research was short. As it was new treatment for learners, the controlled group was deprived of this treatment to check the result on the experimental group.

\subsection{Suggestions for Future Research}

This study, the effect of Self-organized learning environment on the comprehension of ESL learners might be an initiative to use this method of teaching in Pakistan at different levels. Further studies can be conducted on this topic to validate the present study as well. Besides comprehension of English language, other skills like LSRW can be brought under the research by using the SOLE. The same study can be done on vocabulary learning, critical thinking and even learning pronunciation. In addition to all that, teachers can use the same methodology at different levels in school, college and universities. The same can also be researched to find the attitude of ESL learners toward ESL learning. Gender preference for ESL learning can also be researched in the self-organized learning environment. This learning rubric can also be used by the teacher-researchers to explore team work performance as well individual performance for ESL learning.

\section{References}

Barrett, N. E., \& Liu, G.-Z. (2016). Global trends and research aims for English academic oral presentations: Changes, challenges, and opportunities for learning technology. Review of Educational Research, 86(4), 1227-1271. https://doi.org/10.3102/0034654316628296

Card, S. K. (2017). The psychology of human-computer interaction. CRC Press.

Chomsky, N. (1975). Reflections on language. New York: Pantheon.

Chomsky, N. (2000). New horizons in the study of language and mind. Cambridge University Press. https://doi.org/10.1017/CBO9780511811937

Crain, S., \& Nakayama, M. (1987). Structure dependence in grammar formation. Language, 522-543. https://doi.org/10.2307/415004

Descartes, R. (1978). Descartes, his moral philosophy and psychology.

Fong, M. W. (2009). Digital divide: The case of developing countries. Issues in Informing Science and Information Technology, 6(2), 471-478. https://doi.org/10.28945/1074 
Gardner, H. (1987). The mind's new science: A history of the cognitive revolution. Basic books.

Gass, S. M. (2017). Input, interaction, and the second language learner. Routledge. https://doi.org/10.4324/9781315173252

Gottlieb, J., Lopes, M., \& Oudeyer, P.-Y. (2016). Motivated cognition: Neural and computational mechanisms of curiosity, attention, and intrinsic motivation. Recent Developments in Neuroscience Research on Human Motivation (pp. 149-172). Emerald Group Publishing Limited.

Graves, A., Wayne, G., Reynolds, M., Harley, T., Danihelka, I., Grabska-Barwińska, A., ... Agapiou, J. (2016). Hybrid computing using a neural network with dynamic external memory. Nature, 538(7626), 471. https://doi.org/10.1038/nature20101

Jenkins, S. (1990). Second Language Literacy: Functional Competence for the Future. ERIC Clearinghouse.

Kim, J. (2018). Philosophy of mind. Routledge. https://doi.org/10.4324/9780429494857

Kolb, D. A. (2014). Experiential learning: Experience as the source of learning and development. FT press.

Kondo, N., \& Fukumura, Y. (2016). Computer and memory management method: Google Patents.

Lave, J., Wenger, E., \& Wenger, E. (1991). Situated learning: Legitimate peripheral participation (Vol. 521423740). Cambridge university press Cambridge. https://doi.org/10.1017/CBO9780511815355

Medina, J. (2014). Brain rules for baby, Updated and expanded: How to raise a smart and happy child from zero to five. Pear Press.

Mitra, S. (1999). Virtual institutions in the Indian subcontinent. The development of virtual education: A global perspective, 125-134.

Mukti, N. A., \& Hwa, S. P. (2004). Malaysian perspective: Designing interactive multimedia learning environment for moral values education. Educational technology \& society, 7(4), 143-152.

O’Leonard, K. (2013). The corporate learning factbook 2012. Bersin \& Associates (January 2011).

Oudeyer, P. Y., \& Smith, L. B. (2016). How evolution may work through curiosity-driven developmental process. Topics in Cognitive Science, 8(2), 492-502. https://doi.org/10.1111/tops.12196

Peeraer, J., \& Van Petegem, P. (2011). ICT in teacher education in an emerging developing country: Vietnam's baseline situation at the start of 'The Year of ICT'. Computers \& Education, 56(4), 974-982. https://doi.org/10.1016/j.compedu.2010.11.015

Poorfaraj, A., Samimi, A. J., \& Keshavarz, H. (2011). Knowledge and economic growth: Evidence from some developing countries. Journal of Education and Vocational Research, 1(1), 21-25.

Rahimi, M., \& Yadollahi, S. (2011). Computer anxiety and ICT integration in English classes among Iranian EFL teachers. Procedia Computer Science, 3, 203-209. https://doi.org/10.1016/j.procs.2010.12.034

Reid, J. M. (1995). Learning styles in the ESL/EFL classroom. ERIC.

Robertson, M., Fluck, A., \& Webb, I. (2007). Seven steps to success with ICTs: Whole school approaches to sustainable change. Camberwell: ACER Press.

Sharma, A., \& Cockerill, H. (2014). Mary Sheridan's from birth to five years: Children's Developmental Progress. Routledge. https://doi.org/10.4324/9780203494561

Shaw, R., \& Bransford, J. (2017). Perceiving, acting and knowing: Toward an ecological psychology. Routledge.

Sigelman, C. K., \& Rider, E. A. (2014). Life-span human development. Cengage Learning.

Smolin, L., \& Lawless, K. (2007). Technologies in schools: stimulating a dialogue. Yearbook of the National Society for the Study of Education, 106(2), 1-10. https://doi.org/10.1111/j.1744-7984.2007.00119.x

Spradley, J. P. (2016). The ethnographic interview. Waveland Press.

Swenson, R. (1997a). Autocatakinetics, evolution, and the law of maximum entropy production: A principled foundation towards the study of human ecology. Advances in Human Ecology, 6, 1-48.

Swenson, R. (1997b). Evolutionary theory developing: The problem (s) with Darwin's dangerous idea. Ecological Psychology, 9(1), 47-96. https://doi.org/10.1207/s15326969eco0901_3

Weisberg, R. W., \& Reeves, L. M. (2013). Cognition: from memory to creativity. John Wiley \& Sons. 
Wong, L. L., \& Nunan, D. (2011). The learning styles and strategies of effective language learners. System, 39(2), 144-163. https://doi.org/10.1016/j.system.2011.05.004

\section{Notes}

Note 1. http://www.pdfspath.net/get/4/sole_sugata.pdf

Note 2. https://www.theschoolinthecloud.org/partner/khud/\#.Whnf9tTPOuw.whatsapp

\section{Appendix A}

\section{Unseen Comprehension Passage}

In one of the large cities of China there once lived a tailor, whose name was Mustafa who was very poor and found it hard to provide food for himself, his wife, and his only child, Aladdin.

Aladdin was a very naughty and lazy boy. He would never do what his parents want him to do, but played in the streets from morning till night with boys who were as naughty as himself.

When Aladdin was old enough to learn a trade his father took him into own shop and began to show him how to use needle. It was no use. Aladdin had had his own way so long that he could not settle down to work. His father tried him over and over again, and was at last so angry and upset at his son's idle habits that he became ill and soon died.

The poor widow thought that her son would now earn a little money, but he would not. Aladdin was as idle as ever. In despair, she sold all the things that were in the shop, and with this money and the little she earned by spinning cotton she got on fairly well.

Q1. Answer these questions

14

a. In which country did Mustafa live?

b. How did he earn a living?

c. How many children did he have?

d. Name three of Aladdin faults?

Q2. Fill in the blanks. $2 /$

1 The Mustafa was a

2 Aladdin was the __ son of Mustafa.

Q3. Put (T) for true statements and (f) for false statements.

1. Aladdin was a hardworking boy.

2. Aladdin was helpful for his mother

3. Mustafa was a barber.

4. Aladdin's mother earned money by selling fruit.

Q4. Match the followings.

12

Mustafa

Lazy

Aladdin

China

Country

Tailor

Father

Trade

Q5. Complete these.

$$
\begin{aligned}
& \text { F_th_r } \\
& \text { M_ne_ }
\end{aligned}
$$




\section{Appendix B}

Lahore is an old and historical city. It is situated on the bank of River Ravi. It is the capital of the province of the Punjab. There are many historical buildings in city. Badshahi Mosque is one of the biggest mosques in the world. The tomb of Allama Iqbal is beside Shahi Mosque. Iqbal give us idea of Pakistan. The Pakistan Resolution was passed in Lahore. Minare Pakistan was built in commemoration of this resolution. It was built in Iqbal Park.

Q1. Answer these questions

14

a. Where is Lahore situated?

b. What is capital of province Punjab?

C. Where is Allam Iqbal Tomb?

d. Who did give idea of Pakistan?

Q.2 Fill in the blanks.

12

a. gave idea of Pakistan

b. Allama Iqbal tomb is in

Q3. Put $\mathrm{T}$ for true and $\mathrm{F}$ for false statement.

a. Lahore is a new city.

b. Capital of Punjab is Lahore.

Q4. Write two lines about Lahore.

12

Q5. Complete these.

$/ 1$

a. Pro_ence

b. Bi_gest

\section{Copyrights}

Copyright for this article is retained by the author, with first publication rights granted to the journal.

This is an open-access article distributed under the terms and conditions of the Creative Commons Attribution license (http://creativecommons.org/licenses/by/4.0/). 